\title{
Effect of Practice Teaching Schools' Climate on Professional Development of Prospective Teachers in Balochistan
}

\author{
Ghazala Bahadur $^{1}$
}

\begin{abstract}
Practice teaching is a period of professional development in which schools' climate has a great effect on the lives, thoughts and attitude of prospective teachers. Much care is taken in the selection of the content for prospective teachers but no care is taken in the selection of practice teaching schools. Unwillingness of the mentors, lack of support from leadership, unavailable resources, discouraging attitude of the staff and students in practice teaching schools leave an adverse effect on prospective teachers. Good experiences and opportunities contribute to the professional development of prospective teachers but when some of them have bad experiences and unfavorable working environment in their practice teaching schools, they re-think about their choice of teaching profession. The present study was designed to measure the effect of Practice teaching schools' climate on the professional development of male and female prospective teachers. Simple survey was conducted from 145 participants of Quetta city, enrolled in Associate Degree in Education (ADE) / B.Ed (Hons) program through the use of cluster sample technique. Two self-developed questionnaires built on five point Likert scale were used to collect data. SPSS version 20.0 was used for the analysis of data. The findings of the study showed that majority of the participants found positive climate in practice teaching schools where they went for teaching practice. No gender difference was found in professional development of the prospective teachers regarding the effect of positive and negative climate of practice teaching schools.
\end{abstract}

Keywords: Practice teaching, School climate, Prospective teacher, Professional development

\section{Introduction}

It is a fact that the success of the nation depends on its highly educated and skilled man power, which strives for its recognition, honor and prosperity. In the quotes of our great leaders, we find emphasis on educating new generation with skill, care and respect. The duty of educating future generation lies on the

\footnotetext{
${ }^{1}$ MS (Education) Scholar, Department of Education, International Islamic University Islamabad Email: kghazala12@yahoo.com
} 
shoulder of the teachers, so they should be equipped with knowledge, skill and should show good disposition to be modeled by their students. If we want good product (student), first we have to enrich the capabilities of the product maker, the teachers. Rena (2008) affirmed the key role of teachers in implementation of reforms and making difference in students' achievement. Teachers, being a core value for all teaching and learning process, need special education and training before they enter the teaching profession so Government should provide them with opportunities to polish themselves for the assigned task. Rena (2008) stated that every education system which aims to provide quality education to its citizens should rely on its trained, prepared and competent teachers. Mahmood \& Salfi (2012) mentioned quality as the heart of education in which teachers play a crucial role.

A common notion is, "Practice makes man perfect", and therefore, preservice teachers are passed through a process of practicing teaching before joining teaching as a profession. Azeem (2011) referred this teaching practice period, a time when prospective teachers get first-hand experience with a particular group of children. They observe school life, pattern of people's experience, deal with diversified students and also get opportunity of collaboration, a sense of family, connections among staff and the quality of relationships with students (Karen, Jill, Kate, Barry \& Farida, 2015). According to Tok (2011) one of the benefits of this practice is to develop a positive or favorable attitude towards teaching in future teachers. This positive attitude could be developed if a favorable and encouraging environment is experienced by a prospective teacher otherwise challenges of the field can cause change in his/her perception and may result in desertion of teaching profession

Practice teaching is a period of professional development. People use different other names for Professional development, including staff development, in-service training, professional learning or continuing education. Whatever the term is, the purpose is the same - to improve learning of educators and students. Prospective teachers are sent to school for practicing teaching in the real environment of the schools where they get knowledge and experience. The school climate contributes in the professional development of the prospective teachers. It has effect on the knowledge, skill and attitude of both, male and female prospective teachers.

\subsection{Objectives of Study}

The objectives of this study are:-

1. To identify the climate of the practice teaching schools. 
2. To examine gender differences in professional development of the prospective teachers regarding the effect of practice teaching in school's climate.

\subsection{Research Question}

Following research question was formulated which guided the study.

1. What is the climate of the practice teaching schools?

\subsection{Hypotheses}

In order to achieve the objective two, the following hypotheses were formulated:-

$\mathbf{H}_{\mathbf{0 1}}$ : There is no significant difference in the mean Professional Development scores of male PTs and female PTs who experienced positive school climate during teaching practice.

$\mathbf{H}_{\text {02: }}$ There is no significant difference in the mean Professional Development scores of male PTs and female PTs who experienced negative school climate during teaching practice.

\section{Literature Review}

\subsection{Teaching Practice}

Azeem (2011) provides different terms for teaching practice like field studies, student teaching, infield experience, internship or school based experience. It does not matter what term is used for "practice teaching", its main purpose is to provide opportunities to teachers for applying theory into practice under the direct and continuous supervision of experienced masters. Quick and Sieborger (2005) called it a period of transition when a university student becomes classroom teacher. Gujjar, Naoreen, Saifi and Bajwa (2010) stated that during practice teaching, PTs are emotionally involved in school activities and as they get experience in the field, they feel more committed, challenged and even authorized.

During teaching practice, PTs are expected to perform almost all duties which a regular teacher performs in the premises of a school. There they observe all the activities performed inside and outside of the classroom, and also put their knowledge of child psychology, teaching techniques, methods and principles into practice (Gujjar et al., 2010). According to Cakmak (2006), PTs have to teach a couple of the classes supervised by an experienced teacher who could be a teacher of the practice teaching school or a college supervisor, along with participating in the routine activities of school life and contacting with different members of the school such as students, parents and other staff members. Tuli and File (2009) explained practicum as a period of supervised experiences which helps PTs in understanding the scope of teacher's role. 


\subsection{Objectives of Teaching Practice}

Every program has some objectives which help in assessment of that program. The new ADE and B.Ed (Hons) programs in Pakistan have same objectives for teaching practice. Gujjar et al., (2010) mentioned that it provides opportunities to prospective teachers.

1. To establish an appropriate teacher student relationship.

2. To evaluate the potential and suitability of student for this profession.

3. To develop interpersonal relationship with academic and administrative staff and community

4. To experience the ways of overcoming the problems of discipline which will enable him / her to develop method of control?

5. To exchange new methods, ideas, material and equipments between practice teaching schools and teachers' training institution.

6. To plan effective lessons.

7. To develop skill in teaching methods, techniques, principles and procedures.

8. To develop desirable attitude associated with teaching profession.

9. To acquire professional behavior and traits of a teacher

10. To evaluate his/her teaching through the benefits of constructive criticism.

11. To get acquainted with own strengths and weaknesses.

12. To have link with school environment and its resources.

\subsection{School Climate}

Perkins (2007) described school climate as conducive environment for learning, founded through the interaction of physical settings, relationships among humans and psychological atmosphere of the school. School climate not only affects the physical, emotional and intellectual learning of its students but also the educational practices, emotions and perceptions of the perspective teachers who get experiences in these schools during teaching practice. Maier (2010) considered school climate as the quality of the school environment which is experienced by prospective teachers, having effect on their behavior and is based on their collective perceptions of behavior in schools.

According to the definition of National School Climate Centre, School climate is based on the experience of parents, students and school personnel in school life which informs about the goals, interpersonal relationships, norms, teaching and learning practices, values and structure of that organization.

\subsection{Importance of School Climate in Teaching Practice}

School climate has significant role in practice teaching programs because prospective teachers learn the working of a school, with its inside structures, dynamics and relationships (Henning, Petker and Petersen, 2015). Caires, Almeida and Vieira (2012) stated that multiple variables play a key role in 
becoming a teacher such as personal characteristics, guidance of supervisor, student-teachers' resources and characteristics of the placement school.

\subsection{Professional Development}

Mizell (2010) described professional development as educational experiences of different types which are related to the work of an individual. Professional development contributes to the learning of educators which makes their performance better and also results in raising students' achievement. Educators who do not experience effective professional development, lack improvement in their skills due to which students' learning suffers.

\subsection{Researches on Practice Teaching}

Much work has been done on the practice teaching. Different aspects of teaching experience in schools were measured and explained by researchers in different parts of the world. Caires et al., (2005) conducted a study to see the impact of teaching practice on student teachers' personal and professional development. The sample was comprised of 224 PTs of University of Minho (North of Portugal).An inventory consisting on 64 items was adopted for data collection. The results described the main changes occurring in the student teachers' personal and professional development.

Kiggundu and Nayimuli (2009) conducted a study on the PTs of Vaal University of Technology who got the experience of practice teaching in the Vaal(South Africa) area. The study aimed to explain the influence of teaching experiences on prospective teachers' perception of the teaching profession. The participants were interviewed and it was found that despite the positive experiences during teaching practice, PTs experienced challenges which affected their perception of the teaching profession.

Saifi,Sherzaman, Shah, Idress \& Zaman (2013) explored the effect of reformed practicum, proposed in USAID project, on the professional development of PTs in terms of pedagogical skills and beliefs. The sample of 28 B.Ed (Hons) students was selected from University of Gujrat. Data were collected through observation, questionnaire and interviews. The study concluded that PTs' frequent visits to practicum schools, regular meetings with cooperative teacher and supervisor, class room teaching in supervision resulted in positive change in their beliefs about the environment of school, discipline and behavior of the teachers.

Hamaidi et al. (2014) investigated the perspectives of student-teachers about practicum experiences and the challenges faced during practicum. 71 studentteachers of class room teacher and early childhood education studying at the University of Jordan were the sample of the study. The findings revealed that the practicum practices benefited them in acquiring many teaching skills like 
interacting and communicating with students and managing class room, but participants also highlighted challenges such as lack of orientation and support by cooperative teacher, difficulty in communicating with cooperative teacher and lack of guidance by supervisor.

Budiharso's (2015) study aimed to see the role of practicum in improving teacher's professional development. The study was qualitative in nature and 20 student-teachers, who experienced 10-week teaching in Surakarta, were the sample of the study. At the end of teaching practice, semi-structured interviews were conducted from student-teachers. The findings confirmed the significant role of practice teaching in improving teaching performance of student-teacher. The study also found out that class room observation is the means of selfevaluation which improves student-teacher's skills, competence and knowledge in teaching.

\section{Research Methodology}

\subsection{Research Design}

It was a quantitative causal-comparative study by nature which aimed to investigate the effect of practice teaching schools' climate on the professional development of prospective teachers. Simple survey was conducted for data collection.

\subsection{Population}

The $4^{\text {th }}$ semester students of ADE (Session 2014-15) and B.Ed (Hons) (Session 2014-17) program were the population of the study. It comprised 806 students, enrolled in 20 institutions of 13 districts of Balochistan namely Quetta, Pishin, Panjgur, Loralai, Lasbela, Sibi, Killa Saifullah, Mastung, Kalat, Khuzdar, Jaffarabad, Noshki and Kech. Out of total population 361 were male and 445 were female.

\subsection{Sample and Sampling Techniques}

Sample was taken in two steps. In first step, convenient sampling technique was applied and Quetta district was selected as sampling district. Due to poor law and order situation in Balochistan, it was inconvenient for researcher to collect data from other districts. In second step, cluster sampling technique was used and Quetta district was taken as cluster by selecting all PTs of ADE and B.Ed (Hons) ( $4^{\text {th }}$ semester) program as participants of the study. The sample was comprised of 145 prospective teachers (57 male and 88 female) who were taken from the five institutions (3 elementary colleges and 2 universities) situated in district Quetta and were investigated to share their experiences of teaching practice in their respective schools. 


\subsection{Instrumentation}

The data were collected with the help of two self-developed questionnaires for prospective teachers. Questionnaire-1 (26 items) was developed for identifying the climate of practice teaching schools and questionnaire-2(31 items) was developed for measuring the effect of practice teaching schools on the professional development of prospective teachers. Both the questionnaires were scored through five point Likert scale. The instruments were validated by seeking help from the team of experts.

Before the collection of the final data, both the questionnaires were administered to the sample of 20 prospective teachers (10 male and 10 female) of Govt. College of Elementary Education (M \& F) KillaSaifullah, enrolled in ADE program. Five items of questionnaire 1 which had low item-total correlation were excluded from the items of the questionnaire1, so there were 26 items in the final version of questionnaire 1, in which item 1 was about demographic information and 25 items were for identifying practice teaching schools' climate. The Reliability coefficient of questionnaire 1 was 0.727 .

There were 31 items in questionnaire 2, in which item 1 was about demographic information and rest of the items were to measure the effect of practice teaching schools' climate on the professional development of prospective teachers. The Reliability coefficient of this instrument was 0.803 .

As questionnaire 1 was developed to identify the climate of practice teaching schools where PTs went to get teaching experience, so a cut-off point was decided according to the mean scores of 25 items. The detail is given in the table.

Table 3.1

Detail of Cut-off Point for School Climate

Negative school climate Cut-off point Positive school climate

$25-74$

75

$76-125$

Table 3.1 shows that the highest mean score is 125 and the lowest is 25 whereas the median mean score is 75 which is the cut-off point. It was assumed that if the perceived mean score of school climate, obtained by PTs, was equal to or below than 74, it would show the negative school climate and if the obtained mean score fell between the ranges 76-125, it would exhibit the positive school climate. 
In order to see difference in the professional development of male and female PTs, four levels of professional development were decided. The detail of these levels is given in the table.

Table 3.2

Levels of Professional Development

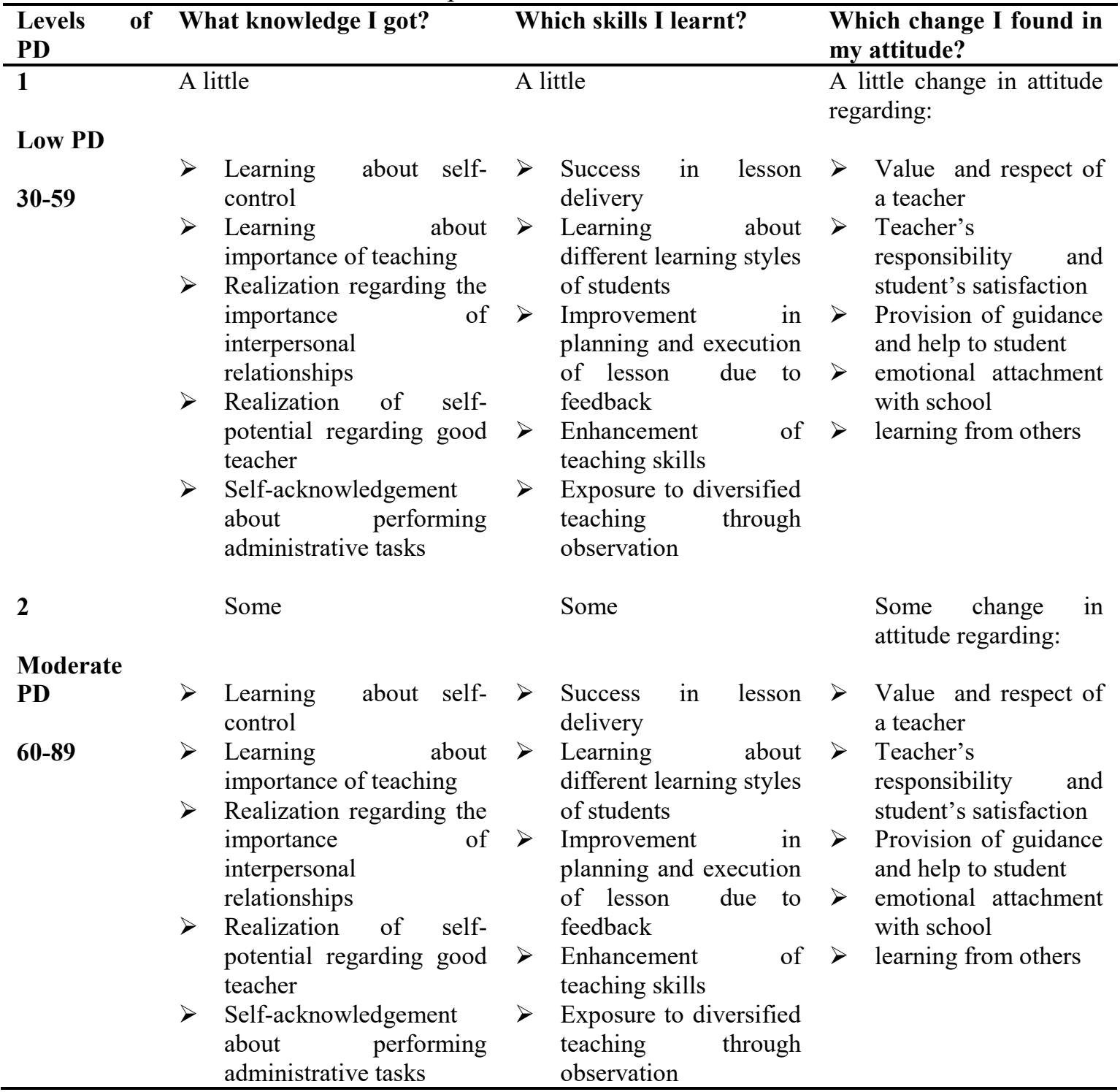


3

High PD

90-119
Much

Learning about selfcontrol

$>$ Learning importance of teaching

$>$ Realization regarding the importance interpersonal relationships

$>$ Realization of selfpotential regarding good teacher

$>$ Self-acknowledgement about performing administrative tasks
Much

A lot of A lot of feedback
Much change in attitude regarding:

Much Value and respect of a teacher

Teacher's responsibility and student's satisfaction of students about Provision of guidance and help to student emotional attachment with school planning and execution of lesson due to Enhancemen teaching skills

Exposure to diversified teaching through observation
4

\section{Very high \\ PD}

120-150

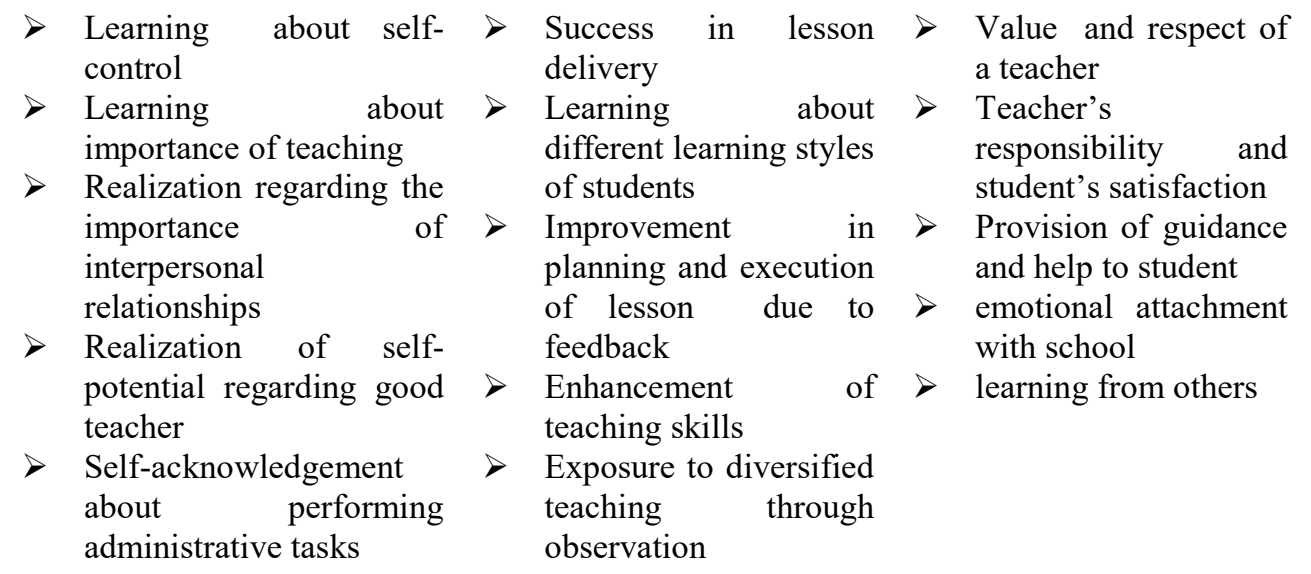

A lot of change in attitude regarding:

Table 3.2 shows four levels of professional development and the description of PD in terms of change in knowledge, skills and attitude. It was assumed that if the perceived mean score of PD of PTs fell between the range 30-59, it would be level 1, showing low PD because PTs got a little knowledge, skills and change in 
their attitude. If the perceived mean score of PD of PTs fell between the range 60-89, it would be level 2, showing moderate PD because PTs got some knowledge, skills and change in their attitude. If the perceived mean score of PD of PTs fell between the range 90-119, it would be level 3, showing high PD because PTs got much knowledge, skills and change in their attitude. If the perceived mean score of PD of PTs fell between the range 120-150, it would be level 4, showing very high PD because PTs got a lot of knowledge, skills and change in their attitude.

\subsection{Data collection}

The researcher visited the sample institutions personally and collected data. Before filling up the questionnaire, the participants were told to recall their teaching practice. They were told that their responses would be kept confidential.

\section{Data Analysis and Interpretation}

The obtained data were analyzed by computing Mean for answering the research question and t-test was applied to test the Null Hypotheses of the study at 0.05 level of significance. The calculations were done through SPSS version 20.

Table 4.1

Detail of Sum of the Means of School Climate

\begin{tabular}{ccc}
\hline Items & $\mathrm{N}$ & Sum of Means \\
\hline 25 & 145 & 84.06
\end{tabular}

Table 4.1 shows that the obtained mean score of 145 participants was 84.06. It shows that the climate of the practice teaching schools was positive where male and female prospective teachers went for practice teaching. Before testing null hypothesis, the number of male and female who experienced positive and negative school climate was computed. The detail is given in the table.

Table 4.2

Nature of Practice Teaching School Climate Experienced by PTs

\begin{tabular}{clllll}
\hline \multirow{2}{*}{ Gender } & \multicolumn{2}{l}{ Positive or Negative School Climate } & \multicolumn{2}{c}{ Total } \\
\cline { 2 - 5 } & 75 & $25-74$ & $76-125$ & & \\
& Cut off point & Negative school climate & Positive school climate & 57 & 57 \\
Male & $4(67 \%)$ & $6(29 \%)$ & $47(40 \%)$ & 88 & 87 \\
Female & $2(33 \%)$ & $15(71 \%)$ & $71(60 \%)$ & 145 & \\
Total & $6(4 \%)$ & $21(15 \%)$ & $118(81 \%)$ & & \\
\hline
\end{tabular}


Table 4.2 shows that 118 prospective teachers found positive school climate while practicing teaching in their respective schools, in which 47 were male and 71were female. 21 PTs found negative school climate in which 6 were male and 15 were female. The sum of the responses of 6 PTs was equal to 75 which failed to determine the nature of the school climate where they went for practice teaching. After finding out the number of PTs, experiencing positive and negative school climate, the formulated null hypothesis were tested by applying independent sample t-test. The calculated values of $\mathrm{Ho}_{1}$ are given in the following table.

Table 4.3

Mean S.D, $t$ and $p$ value of Professional Development of Male and Female PTs who had experienced Positive School Climate.

t-test for Equality of Means

Equal variances assumed

\begin{tabular}{|c|c|c|c|c|c|c|c|c|}
\hline Gender & $\mathrm{N}$ & Mean & S.D & $\begin{array}{l}\text { Std. } \\
\text { Error }\end{array}$ & Sig. & $\mathrm{t}$ & $\mathrm{df}$ & $\begin{array}{l}\text { Sig. (2- } \\
\text { tailed) }\end{array}$ \\
\hline & & & & Mean & & & & \\
\hline Male & 47 & 3.6723 & .25804 & .03764 & .009 & .939 & 116 & .350 \\
\hline Female & 71 & 3.6085 & .41625 & .04940 & & & & \\
\hline
\end{tabular}

Table 4.3 shows that there was no significant difference in the professional development of male and female prospective teachers who had experienced positive school climate for male $(\mathrm{M}=3.67, \mathrm{SD}=.26)$ and for female $(\mathrm{M}=3.61$, $\mathrm{SD}=.42)$ conditions; $\mathrm{t}(116)=.939, \mathrm{p}=.350$.

It shows that the difference between the means of male and female PTs is not significant at 0.05 level. The calculated means suggest that male PTs and female PTs who had experienced teaching practice in positive school climate have attained same level of professional development. Hence Hol"There is no significant difference in the mean Professional Development scores of male PTs and female PTs who experienced positive school climate during teaching practice" is accepted. 


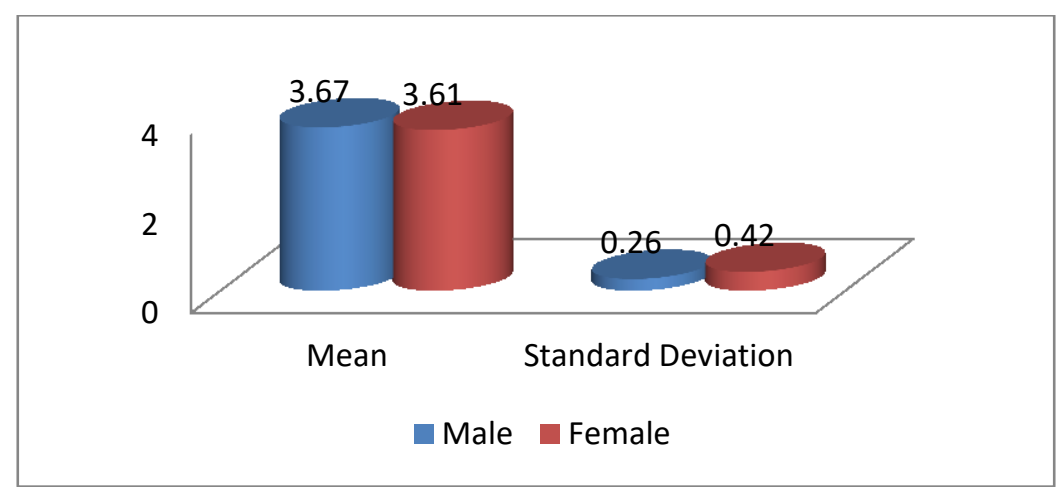

Figure 4.1. Graphical representation of Gender wise difference in Professional Development while experiencing teaching in Positive School Climate

In order to see the level of professional development of male and female PTs, the sum of means of their responses was calculated. Detail is given in table. Table 4.4

Detail of the sum of Means of the Responses of PT who had Experienced Positive School Climate

\begin{tabular}{ccc}
\hline Gender & Items in Questionnaire & Sum of Means \\
\hline Male (47) & 30 & 110.17 \\
Female (71) & 30 & 108 \\
\hline
\end{tabular}

Table 4.4.shows that the calculated mean score of PD of male PTs is 110.17 and female PTs is 108. Both fell between the range of 90-119 which is level 3. It shows high PD and indicates that both male and female PTs got much knowledge, skills and change in their attitude while practicing teaching in positive school climate.

Table 4.5

Mean, S.D, $t$ and $p$ value of Professional Development of Male and Female PTs who had experienced Negative School Climate

t-test for Equality of Means

Equal variances assumed

\begin{tabular}{|c|c|c|c|c|c|c|c|c|}
\hline Gender & $\mathrm{N}$ & Mean & S.D & $\begin{array}{l}\text { Std. } \\
\text { Error } \\
\text { Mean }\end{array}$ & Sig. & $\mathrm{t}$ & $\mathrm{df}$ & $\begin{array}{l}\text { Sig. (2- } \\
\text { tailed) }\end{array}$ \\
\hline Male & 6 & 2.7444 & .53735 & .21937 & .165 & -.682 & 19 & .504 \\
\hline Female & 15 & 2.8933 & .41770 & .10785 & & & & \\
\hline
\end{tabular}


$\mathrm{P}>.05$

Table 4.6 shows that there was no significant difference in the professional development of male and female prospective teachers who had experienced negative school climate for male $(\mathrm{M}=2.74, \mathrm{SD}=.54)$ and for female $(\mathrm{M}=2.89$, $\mathrm{SD}=.42)$ conditions; $\mathrm{t}(19)=-.682, \mathrm{p}=.504$.

It shows that the difference between the means of male and female PTs is not significant at .05 level. The calculated means suggest that male PTs and female PTs who had experienced teaching practice in negative school climate have attained same level of professional development. Hence $\mathrm{Ho}_{2}{ }^{\text {"TThere }}$ is no significant difference in the mean Professional Development scores of male PTs and female PTs who experienced negative school climate during teaching practice" is accepted.

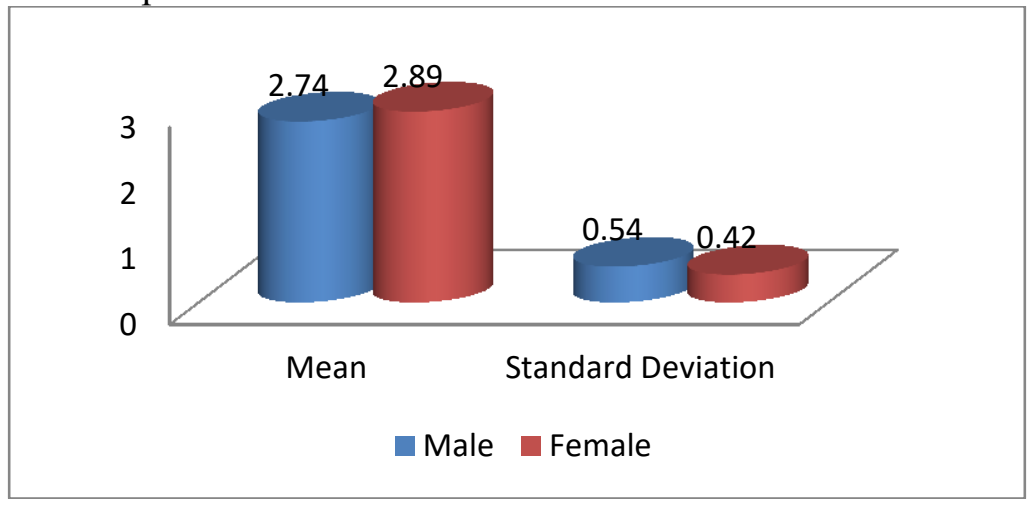

Figure 4.2. Graphical representation of Gender wise difference in Professional Development while experiencing teaching in Negative School Climate

In order to see the level of professional development of male and female PTs, the sum of means of their responses was calculated. Detail is given in table. Table 4.6

Detail of the sum of means of the responses of PT who had Experienced Negative School Climate

\begin{tabular}{ccc}
\hline Gender & Items in Questionnaire & Sum of Means \\
\hline Male (6) & 30 & 98.5 \\
Female (15) & 30 & 94.6 \\
\hline
\end{tabular}

Table 4.6 shows that the calculated mean score of PD of male PTs is 98.5 and female PTs is 94.6. Both fell between the range of 90-119 which is level 3. It shows high PD and indicates that both male and female PTs got much 
knowledge, skills and change in their attitude while practicing teaching in negative school climate

\section{Discussion and Conclusion}

The study is conducted to identify the climate of practice teaching schools. The results of the study showed that the majority of the PTs found positive school climate in their respective schools which is a good sign of change. One of the reasons of this change is that for new pre-service teacher education programsADE and B.ED (Hons), different trainings were conducted in Quetta city by Bureau of Curriculum and Extension Centre in collaboration with Pre-STEP. They conducted trainings for supervisors, co-operative teachers and heads of the institutions regarding their responsibilities and the way of guiding and facilitating PTs. These trainings really helped in bringing positive change in their mind set and behavior. As a result, PTs no longer faced the challenges in practice teaching schools which they were facing before.

The results of the study showed that there is no difference in the mean professional development scores of male and female PTs who experienced positive school climate during teaching practice. Both attained the same level of professional development. These findings are logical that positive school climate influenced much knowledge, skill and attitude of male and female PTs. The study of Caires and Almeida (2012) had shown the same result by counting the benefits of practice teaching. The results of the study showed that there is also no difference in the mean professional development scores of male PTs and female PTs who experienced negative school climate during teaching practice. They faced many difficulties but they continued their teaching practice in negative environment of the school and attained much knowledge about their strengths and weaknesses. They enhanced their skill of lesson planning and delivery, diversified teaching through observation and different learning styles of students. It also brought change in their attitude regarding value and responsibilities of the teacher, provision of guidance and help to student, emotional attachment with school and learning from others. The findings of the study are parallel with the findings of Caires et al. (2012) which pointed out multiple achievements and gains (knowledge, skill, sense of efficacy, flexibility and interactions) of PTs, during practice teaching while facing many difficulties.

To sum up the discussion, practice teaching contributes in the professional development of PTs. They will learn more if favorable environment is provided to them in the school which they visited for teaching purpose. 


\section{Recommendations}

1. Authorities may arrange trainings for supervisors, co-operative teachers and heads of institutions for telling and realizing the responsibility of guiding and facilitating PTs.

2. Training institutions may arrange regular meetings with Heads of practicum schools to establish good relations with them.

3. Government may provide additional increment in salary to co-operative teachers as a sign of appreciation and motivation for facilitating PTs.

4. Practicum coordinator and supervisor may arrange frequent visits to practicum schools to solve the problems of PTs immediately.

5. Practicum co-coordinator may arrange monthly meetings with Heads of practicum schools for the purpose to inform them about the behavior and support of their staff and students which PTs receive in their school.

\section{References}

Almeida, S. C. (2005). Education: Its impact on Student Teachers' Professional Skills and Developent. Journal of Education for Teaching, 3(2), 111120.

Azeem, M. (2011). Problems of Prospective Teachers During Teaching Practice. Academic Research International, 1(2).

Budiharso, T. (2015). Teaching Practice: Does it Substantiate Teacher's Profession Developmentt? Pedagogik, 8(1), 34-46.

Caires, S., Almeida, L., \& Veira, D. (2012). Becoming a Teacher: Student Teachers' Experiences and Perceptions. European Journal of Teacher Education, 35(2), 163-178.

Cakmak, M. (2006). The Expectations and Views of Teacher Candidates about School Experience: A Case Study. Gazi University, Ankara, Turky, Gazi Education faculty.

Gujjar, A. A., Noreen, B., Saifi, S., \& Bajwa, J. (2010). Teaching Practice: Problems and Issues in Pakistan. International Online Journal of Educational Sciences, 339-361.

Hamaidi, D., Al-Shara, I., Arouri, Y., \&Awwad, F. A.(2014). StudentT-Teachers' Perspectives of Practicum Practices and Challenges. European Scientific Journal, 10(13), 191-214. 
Henning, E., Petker, G., \& Petersen, N. (2015). University-Affiliated Schools as sites for Research Learning in Pre-Service Teacher Education. South African Journal of Education, 35(1).

Karen, R., Jill, A., Kate, A., Barry, F., \& Farida, F. (2015). Creating a Climate in which Students Can Flourish:A Whole School Intercultural Approach. InternationalL Journal of Whole Schooling, 11(2), 29-44.

Kiggundu, E., \& Nayimuli, S. (2009). Teaching Practices: A Make or Break Phase for Student Teacher. South Africa Journal of Education, 29, 345358.

Mahmood, N., \& Salfi, N. A. (2012). Professional Standards Imperatives: Future Teacher. International Researcher, 1(1), 17-32.

Maier, S. (2010). Assessing School Climate Using A Sequential Transformative Design. Colorado Statae University Fort Collins, Colorado.

Mizell, H. (2010). Why Professional Development Matters. (V. v. Frank, Ed.) United States of America.

Perkins, K. B. (2007). Where We Teach: The CUBE Survey of Urban School Climate. Stephanie Wikberg Design.

Quick, G. \&Siebörger, R. (2005). What Matters in Practice Teaching? The Perceptions of Schools and Students. South Africa Journal of Education, $25,1-4$.

Rena, R. (2008). Perception of Pre-Service Teachers Towards Teaching: A Case Study on the Eritrea Institute of Technology. Review of Higher Education in Africa.

Saifi, S., Sherzaman, Shah, S. S., Idress, A., \& Zaman, S (2013). Effect of Reformed Teaching Practicum on Professional Development of B.Ed (Hons) Prospective Teachers. Bulletin of Education and Research, 35(2), 125-138.

Tok, S. (2011). Pre-service Primary Education teacher's Changing attitude Towards Teaching:A Longitudinal Study. European Journal of Teacher Education, 34(1), 81-97. 
International Journal of Innovation in Teaching and Learning (IJITL)

Volume I- Issue II (December 2015)

Tuli, F., \& File, G. (2009). Practicum Experience in Teacher Education. Ethiopian Journal of Education \& Science, 5, 107-116. 